\title{
Differentiation of Nocardioform Actinomycetes by Lysozyme Sensitivity
}

\author{
By HALINA MORDARSKA, S. CEBRAT AND BOZENA BLACH \\ Institute of Immunology and Experimental Therapy, \\ Polish Academy of Sciences, Wroclaw, Poland \\ AND M. GOODFELLOW \\ Department of Microbiology, The Medical School, \\ The University, Newcastle upon Tyne NE1 7RU
}

(Received 17 May 1978; revised 1 August 1978)

\section{INTRODUCTION}

Modern taxonomic methods have helped to clarify the relationships between actinomycetes that reproduce by the fragmentation of all, or more or less accidentally involved parts, of their hyphae into bacillary and coccoid elements (Goodfellow \& Minnikin, 1977; Mordarska, 1977). Improved classification provides a framework for recognizing and developing tests of value for identification. Simple and reliable tests are particularly required for the identification of mycolic acid-containing bacteria with a wall chemotype IV that are classified in the genera Corynebacterium, Mycobacterium, Nocardia and Rhodococcus (Goodfellow, 1973; Goodfellow \& Minnikin, 1978). Related actinomycetes received as Gordona aurantiaca and as aurantiaca-like strains are in need of further study to clarify their taxonomy (Goodfellow \& Alderson, 1977; Goodfellow et al., 1978).

The sensitivity of actinomycetes to lysozyme has been studied frequently (Romano \& Sohler, 1956; Sohler et al., 1958) and is used in the classification and identification of mycobacteria, nocardiae and related strains (Gordon, 1966; Gordon et al., 1974; Lechevalier \& Lechevalier, 1974; Gordon \& Barnett, 1977). The lysozyme (lytic) test described below provides a convenient way of distinguishing nocardiae, mycobacteria and G. aurantiaca strains from related bacteria.

\section{METHODS}

Strains. Two hundred representatives of the genera Actinomadura, Corynebacterium, Micromonospora, Micropolyspora, Mycobacterium, Nocardia, Nocardioides, Pseudonocardia, Rhodococcus and Streptomyces and related strains were studied (Table 1). Cultures were maintained on glucose yeast extract agar at room temperature (Gordon \& Mihm, 1962).

Lysozyme test. Strains were grown in submerged cultures in glucose yeast extract broth at $30^{\circ} \mathrm{C}$ (Prauser $\&$ Falta, 1968). At stationary phase, $5 \mathrm{ml}$ amounts of broth were centrifuged and the pellets were resuspended in sterile distilled water after grinding the organisms where necessary. The suspensions were diluted with distilled water, to give an absorbance $(0 \cdot 2$ to $0 \cdot 25)$ corresponding to that of an Escherichia coli suspension containing about $3 \times 10^{8}$ cells ml ${ }^{-1}$, and transferred to calibrated test tubes. To $0.7 \mathrm{ml}$ of suspension, $0.4 \mathrm{ml}$ of a $1 \%(\mathrm{w} / \mathrm{v})$ aqueous solution of freshly prepared Bacto-lysozyme (Difco) was added, and the mixture was incubated for $3 \mathrm{~h}$ at $37^{\circ} \mathrm{C} ; 0.7 \mathrm{ml}$ of a $20 \%(\mathrm{w} / \mathrm{v})$ aqueous solution of sodium dodecyl sulphate (SDS, Sigma) was then added. After thorough mixing, the turbidity of the suspension was compared with that of control suspensions. In each series of tests the controls included known lysozyme-resistant and -sensitive strains. A negative control was also prepared by incubating $7 \mathrm{ml}$ of bacterial suspension with $0.4 \mathrm{ml}$ distilled water for $3 \mathrm{~h}$ at $37^{\circ} \mathrm{C}$ and then adding $0.7 \mathrm{ml}$ distilled water in place of the SDS solution. The SDS solution can be stored at room temperature but should be warmed before use, to dissolve the SDS completely, and then allowed to cool to room temperature.

Nocardia amarae, $N$. asteroides, $N$. autotrophica and Rhodococcus erythropolis strains that were either not lysed or only partially lysed were re-tested using cells defatted with ethanol/diethyl ether $(1: 1, \mathrm{v} / \mathrm{v})$ or chloroform/methanol $(2: 1, \mathrm{v} / \mathrm{v})$. 


\section{RESULTS AND DISCUSSION}

By means of the lysozyme test, nocardioform and related bacteria can be divided into three groups. Thus, strains more or less completely lysed were scored positive, those showing no or only a small degree of lysis were scored negative, while suspensions showing an absorbance of about half that of the initial suspension were considered to be partially lysed (Table 1).

The lysozyme-resistant group is composed mainly of $G$. aurantiaca strains, mycobacteria (with the exception of M.album) and true nocardiae, i.e. $N$. asteroides, $N$.brasiliensis, N.carnea, $N$. otitidis-caviarum and N. transvalensis (Goodfellow \& Minnikin, 1977). Mycobacterium album is currently listed as a species incertae sedis (Runyon et al., 1974). It is one of a few fast-growing mycobacteria resistant to $200 \mathrm{mg}$ isonicotinamide hydrazide $\mathrm{ml}^{-1}$ (Orlean et al., 1978) and its classification needs further study. Further systematic work is also required to find a niche for the $G$. aurantiaca strains, which form a taxon equivalent to, but clearly separate from, Mycobacterium, Nocardia and Rhodococcus (Goodfellow et al., 1978), and to determine their relationship to lysozyme sensitive aurantiaca-like bacteria. The sensitivity or partial sensitivity of $N$. autotrophica strains provides additional evidence for distinguishing them from true nocardiae. Nocardia autotrophica strains have a wall type IV but unlike true nocardiae they lack mycolic acids and possess high proportions of iso and anteiso fatty acids (Goodfellow \& Minnikin, 1977; Kroppenstedt \& Kützner, 1978).

With few exceptions the representatives of the genera Corynebacterium, Micropolyspora, Nocardioides, Oerskovia, Pseudonocardia, Rhodococcus and Streptomyces were lysozymesensitive and could thereby be readily distinguished from nocardiae, mycobacteria and G. aurantiaca strains. In all cases, organisms extracted with the organic solvents behaved like undefatted cells.

The finding that lysozyme resistance is a characteristic property of most nocardiae, mycobacteria and $G$. aurantiaca strains is of interest both in the differentiation of these organisms from related bacteria and in the context of the mode of action of the enzyme. The lysozyme test should be useful in clinical laboratories for the differentiation of mycobacteria and nocardiae from corynebacteria and rhodococci since it limits the number of taxa to be considered in the preliminary identification of nocardioform bacteria. The test also provides a convenient way of distinguishing true nocardiae from streptomycetes and may prove to be useful in distinguishing Actinomadura species (Table 1). The method might also be of value in determining the sensitivity of bacteria to lysozyme prior to the extraction of DNA and RNA for reassociation assays.

The results of the present study are in general agreement with those of Gordon \& Barnett (1977) who examined the sensitivity of nocardiae, mycobacteria and related actinomycetes to lysozyme. However, the two lysozyme tests are different and the results also show some differences; for example, Gordon \& Barnett (1977) found that all $N$. autotrophica, A. dassonvillei and $A$. pelletieri, and most $M$. phlei and $M$. smegmatis, strains were sensitive to lysozyme. The method described here has been shown to separate important genera and has the additional advantage that it can be carried out relatively quickly. However, both methods have advantages and disadvantages and should be applied to a selected collection of strains to determine their reproducibility and differential power.

The differences in the sensitivity of actinomycetes to lysozyme presumably reflect structural differences in the wall. Lysozyme acts on the glycan moiety of the peptidoglycan which in most actinomycetes is $\mathrm{N}$-acetylated muramic acid, but in true nocardiae, mycobacteria and micromonosporae the muramic acid is $N$-glycolylated (Azuma et al., 1970; Kanetsuna \& San Blas, 1970; Vilkas et al., 1970; Michel \& Bordet, 1976). It is premature to 
Table 1. Sensitivity of the test strains to lysozyme

\begin{tabular}{|c|c|c|c|c|c|c|c|c|}
\hline Taxon & $\begin{array}{l}\text { No. of } \\
\text { strains* }\end{array}$ & + & $\underbrace{\text { Result }}_{ \pm-}$ & Taxon & $\begin{array}{c}\text { No. of } \\
\text { strains* }\end{array}$ & & $\overbrace{ \pm}^{\text {Resul }}$ & \\
\hline Actinomadura dassonvillei & 5 & 3 & 2 & N. brasiliensis & 3 & & & 3 \\
\hline A. madurae & 2 & 2 & & N. carnea & 2 & & & 2 \\
\hline A. pelletieri & 3 & & 3 & N. marina & 1 & & & 1 \\
\hline A. pusilla & 1 & 1 & & $N$. otitidis-caviarum & 2 & & & 2 \\
\hline A. roseoviolacea & 1 & & 1 & N. transvalensis & 2 & & & $\overline{0}$ \\
\hline A. verrucosospora & 1 & & 1 & Nocardioides albus & 4 & 4 & & \\
\hline Corynebacterium diphtheriae & 2 & 2 & & N. luteus & 2 & 2 & & \\
\hline C. glutamicum & 1 & 1 & & Oerskovia turbata & 2 & 2 & & \\
\hline C. hoagii & 1 & 1 & & Pseudonocardia thermophila & 1 & 1 & & \\
\hline C. pseudodiphtheriticum & 1 & 1 & & Pseudonocardia spp. & 3 & 3 & & \\
\hline C. xerosis & 2 & 2 & & Rhodococcus bronchialis & 2 & 2 & & \\
\hline Gordona aurantiaca & 8 & & 8 & $R$. coprophilus & 2 & 2 & & \\
\hline aurantiaca-like strains & 9 & 7 & 2 & $R$. corallinus & 3 & 3 & & \\
\hline Micromonospora chalcea & 1 & & 1 & R. equi & 8 & 8 & & \\
\hline Micromonospora narashino & 1 & & 1 & R. erythropolis & 10 & 5 & 2 & 3 \\
\hline Micromonospora parva & 1 & & 1 & R. rhodnii & 3 & & 2 & 1 \\
\hline Micromonospora spp. & 3 & 3 & & $R$. rhodochrous & 4 & 4 & & \\
\hline Micropolyspora faeni & 3 & 3 & & R. rubropertinctus & 5 & 5 & & \\
\hline Micropolyspora fascifera & 1 & 1 & & R. ruber & 27 & 27 & & \\
\hline Micropolyspora rectivirgula & 1 & 1 & & R. terrae & 2 & 2 & & \\
\hline Mycobacterium album & 1 & 1 & & Rhodococcus spp. & 6 & 6 & & \\
\hline M. aurum & 1 & & 1 & Streptomyces albus & 1 & 1 & & \\
\hline M. borstelense & 1 & & 1 & S. celluloflavus & 1 & 1 & & \\
\hline M. bovis & 1 & & 1 & S. citreus & 1 & 1 & & \\
\hline M. diernhoferi & 1 & & 1 & S. fradiae & 1 & 1 & & \\
\hline M. flavescens & 1 & & 1 & S. globisporus & 1 & 1 & & \\
\hline$M$. parafortuitum & 1 & & 1 & S. griseostramineus & 1 & 1 & & \\
\hline M. phlei & 2 & & 2 & S. griseus & 1 & 1 & & \\
\hline M. smegmatis & 3 & & 3 & S. malachiticus & 1 & 1 & & \\
\hline M. thermoresistibile & 1 & & 1 & S. olivaceus & 2 & 2 & & \\
\hline M. tuberculosis H37Ra & 1 & & 1 & S. venezuelae & 1 & 1 & & \\
\hline Nocardia amarae & 9 & 3 & 6 & S. violaceorectus & 1 & 1 & & \\
\hline N. asteroides & 15 & & 15 & S. viridifaciens & 1 & 1 & & \\
\hline N. autotrophica & 7 & 2 & 41 & & & & & \\
\hline
\end{tabular}

relate lysozyme sensitivity in actinomycetes solely to the presence of $N$-acetylated muramic acid and lysozyme resistance to the presence of the $N$-glycolylated type, especially since it has been demonstrated that in other bacteria the sensitivity of the peptidoglycan lytic enzymes can be influenced by other wall components (Mosser \& Tomasz, 1970). The influence of wall components other than the peptidoglycan may explain the sensitivity of some of the micromonosporae to lysozyme. Uchida \& Aida (1977) have devised a micromethod for differentiating between $N$-glycolyl and $N$-acetyl wall types, which may help to elucidate the basis of the lytic test.

The authors would like to thank Dr H. Prauser, Institute of Microbiology and Experimental Therapy, Jena, DDR, for strains of Actinomadura, Micropolyspora and Nocardioides and Miss B. Mittelstaedt for technical assistance. 


\section{REFERENCES}

Azuma, J., Thomas, D. W., Adam, A., Ghuysen, J.-M., Bonaly, R., Petit, J.-F. \& Lederer, E. (1970). Occurrence of $N$-glycolylmuramic acid in bacterial cell walls. Biochimica et biophysica acta 208, 444-451.

Goodfellow, M. (1973). Characterisation of Mycobacterium, Nocardia, Corynebacterium and related taxa. Annales de la Société belge de médecine tropicale 53, 287-298.

Goodfellow, M. \& Alderson, G. (1977). The actinomycete-genus Rhodococcus: a home for the 'rhodochrous' complex. Journal of General Microbiology 100, 99-122.

GoOdfellow, M. \& MinNIKIN, D. E. (1977). Nocardioform bacteria. Annual Review of Microbiology 31, 159-180.

Goodfellow, M. \& MinNikin, D. E. (1978). Numerical and chemical methods in the classification of Nocardia and related taxa. In Nocardia and Streptomyces, pp. 43-51. Edited by M. Mordarski, W. Kuryłowicz \& J. Jeljaszewicz. Stuttgart: Gustav Fischer Verlag.

Goodfellow, M., Orlean, P. A. B., Collins, M. D., Alshamaony, L. \& Minnikin, D. E. (1978). Chemical and numerical taxonomy of strains received as Gordona aurantiaca. Journal of General Microbiology 109, 57-68.

GoRDon, R. E. (1966). Some criteria for the recognition of Nocardia madurae (Vincent) Blanchard. Journal of General Microbiology 45, 355-364.

GORDON, R. E. \& BARNETT, D. A. (1977). Resistance to rifampin and lysozyme of strains of some species of Mycobacterium and Nocardia as a taxonomic tool. International Journal of Systematic Bacteriology 27, 176-178.

GoRdon, R. E. \& Mıнм, J. H. (1962). Identification of Nocardia caviae (Erikson) nov.comb. Annals of the New York Academy of Sciences 98, 628636.

Gordon, R. E., Barnett, D. A., Handerham, J. E. \& PANG, C. H. N. (1974). Nocardia coeliaca, Nocardia autotrophica, and the nocardin strain. International Journal of Systematic Bacteriology 24, 54-63.

Kanetsuna, F. \& San Blas, G. (1970). Chemical analysis of a mycolic-acid-arabinogalactanmucopeptide complex of mycobacterial cell wall. Biochimica et biophysica acta 208, 434-443.

KROPPENSTEDT, R. M. \& KüTZNER, H. J. (1978). Biochemical taxonomy of some problem actinomycetes. In Nocardia and Streptomyces, pp. 125133. Edited by M. Mordarski, W. Kuryłowicz \& J. Jeljaszewicz. Stuttgart: Gustav Fischer Verlag.
Lechevalier, M. P. \& Lechevalier, H. A. (1974). Nocardia amarae sp.nov., an actinomycete common in foaming activated sludge. International Journal of Systematic Bacteriology 24, 278-288.

Michel, G. \& BoRdeT, C. (1976). Cell walls of nocardiae. In The Biology of the Nocardiae, pp. 141-159. Edited by M. Goodfellow, G. H. Erownell \& J. A. Serrano. London: Academic Press.

MORDARSKA, H. (1977). The nocardioform actinomycetes. Postepy mikrobiologii 16, 43-54.

Mosser, J. L. \& Tomasz, A. (1970). Choline containing teichoic acid as a structural component of pneumococcal cell wall and its role in sensitivity to lysis by an autolytic enzyme. Journal of Biological Chemistry 245, 287-298.

Orlean, P. A. B., Goodfellow, M. \& MinNikin, D. E. (1978). Isoniazid sensitivity as a criterion for the differentiation of mycobacterial species from other mycolic acid containing taxa. International Journal of Systematic Bacteriology 28, 194-196.

Prauser, H. \& Falta, R. (1968). Phagen-Sensibilität, Zellwandzusammensetzung und Taxonomie von Actinomyceten. Zeitschrift für allgemeine Mikrobiologie 8, 39-46.

Romano, A. H. \& SoHLer, A. (1956). Eiochemistry of the Actinomycetales. II. A comparison of the cell wall composition of the species of the genera Streptomyces and Nocardia. Journal of Bacteriology 72, 865-868.

Runyon, E. H., Wayne, L. G. \& Kubica, G. P. (1974). Family II. Mycobacteriaceae Chester 1897, 63. In Bergey's Manual of Determinative Bacteriology, 8th edn., pp. 681-701. Edited by R. E. Buchanan \& N. E. Gibbons. Baltimore: Williams \& Wilkins.

Sohler, A., Romano, A. H. \& Nickerson, W. J. (1958). Eiochemistry of the Actinomycetales. III. Cell wall composition and the action of lysozyme upon cells and cell walls of the Actinomycetales. Journal of Bacteriology 75, 282-290.

UCHIDA, K. \& AIDA, K. (1977). Acyl type of bacterial cell wall: its simple identification by colorimetric method. Journal of General and Applied Microbiology 23, 249-260.

Vilkas, E., Massot, J. C. \& Zissman, E. (1970). Étude des parois d'une scuche de Micromonospora. I. Isolement d'un phosphate de glucosamine. FEBS Letters 7, 77-79. 